\title{
THE ELUSIVENESS OF SELF-DEFENSE FOR THE BLACK TRANSGENDER COMMUNITY
}

\author{
Shawn E. Fields* \\ INTRODUCTION
}

Ky Peterson, a Black transgender man from rural Georgia, had previously been brutally raped while walking home. ${ }^{1} \mathrm{Mr}$. Peterson reported the incident to the police, but they never opened an investigation;" in fact, the police "could barely be bothered to file [a] report." ${ }^{3}$ As a result, Mr. Peterson began carrying a firearm for personal protection. ${ }^{4}$

On October 28, 2011, Mr. Peterson was again attacked and raped..$^{5}$ The man-whose advances Mr. Peterson had rejected earlier that nightapproached Mr. Peterson from behind and struck him in the head, rendering him unconscious. ${ }^{6}$ When Mr. Peterson awoke, the stranger was on top of him, penetrating him while hurling transphobic insults at him. ${ }^{7}$ After a lengthy struggle, Mr. Peterson reached for his handgun and killed the attacker. ${ }^{8} \mathrm{Mr}$. Peterson later reported the incident to the police and completed a rape kit, which confirmed the brutal nature of his sexual assault. ${ }^{9}$ Nevertheless, police dismissed his claims of rape and self-defense, charging him with "armed robbery,

* Assistant Professor of Law, Campbell University School of Law; J.D., Boston University School of Law; B.A., Yale University. Many thanks to the editors of the Nevada Law Journal for holding this important symposium and for their tireless work on this Essay. All errors are my own.

1 See Sunnivie Brydum \& Mitch Kellaway, This Black Trans Man Is in Prison for Killing His Rapist, AdvOCATE (Apr. 8, 2015, 11:15 AM), https://www.advocate.com/politics/transge nder/2015/04/08/black-trans-man-prison-killing-his-rapist [https://perma.cc/S7H4-ABQP]; see also Samone Ijoma, False Promises of Protection: Black Women, Trans People \& the Struggle for Visibility as Victims of Intimate Partner and Gendered Violence, 18 U. MD. L.J. RACE, Religion, Gender \& Class 255, 268 (2018).

${ }^{2}$ Brydum \& Kellaway, supra note 1.

${ }^{3}$ Id.

${ }^{4} I d$.

${ }^{5} I d$.

${ }^{6}$ Id.

${ }^{7}$ Id.

${ }^{8}$ Id.

${ }^{9} I d$. 
aggravated assault, malice murder, two counts of felony murder, and three counts of possession of a firearm during the commission of a felony." 10

Mr. Peterson's actions arguably fell within the traditional common law definition of self-defense. ${ }^{11}$ But they clearly fell within Georgia's expansive Stand Your Ground laws, providing among the broadest scope of self-defense protection for the use of lethal force in public of any state in the country. ${ }^{12}$ Mr. Peterson's defense lawyer did not even assert a Stand Your Ground defense on his behalf, claiming that his race and gender identity would make such a defense useless before a rural Georgia jury. ${ }^{13}$ While Mr. Peterson asserted self-defense, he was convicted and sentenced to twenty years in prison. ${ }^{14}$

This story poignantly illustrates the systemic under-enforcement and overenforcement of the Black transgender community by law enforcement. Transgender people of color, particularly Black transgender individuals, "experience violence at a disproportionate rate" in the United States. ${ }^{15}$ Black transgender men and women are more likely than their White transgender counterparts - and many times more likely than the general population-to "experience virtually every category of violence, including transphobic family violence, violence in schools and places of public accommodation, and police and prison violence." 16 Black transgender individuals face among the highest domestic violence rates in the country. ${ }^{17}$ And murders of Black transgender individuals have risen dramatically in recent years and are almost certainly underreported. ${ }^{18}$

${ }^{10} \mathrm{Id}$.

${ }^{11}$ See Tamara Rice Lave, Shoot to Kill: A Critical Look at Stand Your Ground Laws, 67 U. MiA. L. REv. 827, 832-33 (2013) (describing the difference between Stand Your Ground legislation and traditional self-defense doctrine, which requires a reasonable belief of imminent deadly force and a proportional use of force to repel that danger).

12 See Ga. Code AnN. § 16-3-23.1 (West, Westlaw through 2020 Legis. Sess.); see also Stand Your Ground, GIFFORDS L. CTR., https://giffords.org/lawcenter/gun-laws/policy-areas/ guns-in-public/stand-your-ground-laws [https://perma.cc/55U2-PR8C] (summarizing the scope of Stand Your Ground laws across the country).

${ }^{13}$ Ijoma, supra note 1, at 269 ("His lawyer did not even present Peterson with a Stand-YourGround defense as an option because he knew such a defense would likely be unsuccessful given Peterson's racial and gender identity."); see also CARoline E. Light, STAND Your Ground: A History of AmERICA's Love AfFAIR With Lethal SELF-DeFENSE 183 (2017).

14 Ijoma, supra note 1, at 269.

15 See Carrie L. Buist, LGBTQ Rights in the Fields of Criminal Law and Law Enforcement, 54 U. Rich. L. REV. 877, 897-98 (2020) (observing that Black transgender individuals "are the victims of especially brutal murders in [America]").

${ }^{16}$ Gabriel Arkles, Gun Control, Mental Illness, and Black Trans and Lesbian Survival, 42 Sw. L. REv. 855, 860 (2013).

17 See Leonore F. Carpenter \& R. Barrett Marshall, Walking While Trans: Profiling of Transgender Women by Law Enforcement, and the Problem of Proof, 24 WM. \& MARY J. WOMEN \& L. 5, 9 (2018); see also Buist, supra note 15, at 897.

${ }_{18}$ Carpenter \& Marshall, supra note 17, at 9, 29 n.119. 
But as illustrated in Mr. Peterson's case, police intervention and protection for this community remain sorely lacking. Years of anecdotal evidence and recent alarming empirical data show a disturbing ambivalence (or worse) from police when responding to reports of violence by Black trans victims. ${ }^{19}$ "Transgender victims of domestic violence report that calling the police frequently results in the transgender victim being arrested, violence from the police, or a total failure to respond to the situation." 20 Black transgender women regularly report police failing to take reports of violence seriously, because the victim is "really a man." ${ }^{21}$ Indeed, transgender victims of all backgrounds are often as likely to be harassed or sexually abused by police when reporting a crime as they are to have their claims treated seriously and investigated. ${ }^{22}$

Given this systemic lack of protection from the criminal legal system, Black transgender individuals like Mr. Peterson increasingly must rely on selfprotective measures to repel the disproportionate rates of violence to which they are subjected. But exercising lawful self-defense exposes the Black transgender community to police over-enforcement of their lawful actions. In this sense, the community feels the dual effects of historic criminalization of the Black community and the transgender community. The centuries' long over-criminalization and over-enforcement of the Black community by police is well-documented, including in the availability (or lack thereof) of selfdefense to Black individuals lawfully repelling a violent attack. ${ }^{23}$ Rather than providing an opportunity for expanded self-defense protection, Stand Your Ground laws have only reinforced the racially disproportionate impact of selfdefense assertions in criminal adjudications. ${ }^{24}$

19 See Amnesty Int'l, United States of America: Stonewalled: Police Abuse And Misconduct Against Lesbian, Gay, Bisexual and Transgender People in the U.S. 72, 125-26(2005).

${ }^{20}$ Carpenter \& Marshall, supra note 17 ("These experiences make transgender violence victims believe that the police offer very little safety and, in fact, support a belief that they may be more dangerous than perpetrators of violence such as domestic abusers.").

${ }^{21}$ See id.; see also Kae Greenberg, Still Hidden in the Closet: Trans Women and Domestic Violence, 27 BERKELEY J. GENDER L. \& JUST. 198, 231-32 (2012).

${ }^{22}$ Greenberg, supra note 21, at 230-31, 234.

${ }^{23}$ See, e.g., Cynthia Lee, Making Race Salient: Trayvon Martin and Implicit Bias in a Not yet Post-Racial Society, 91 N.C. L. Rev. 1555, 1555, 1589 (2013) [hereinafter Lee, Making Race Salient] (describing the "especially problematic" influence racial bias has on jurors assessing "claims of self-defense" by Black defendants); Cynthia Kwei Yung Lee, Race and Self-Defense: Toward a Normative Conception of Reasonableness, 81 MinN. L. REv. 367, 374 (1996) ("[S]tereotyping can influence decisionmaking [sic] in self-defense cases."); Addie C. Rolnick, Defending White Space, 40 CARDOZo L. Rev. 1639, 1673-74 (2019) (critiquing the "facially race-neutral" laws of self-defense that implicitly incorporate racial fear into the assessment of "reasonableness").

24 A.B.A., National Task Force on Stand Your Ground Laws: Final Report and RECOMMENDATIONS 12-13 (2015); The Inherent Danger of Stand Your Ground Laws, Everytown (Feb. 8, 2019) (citing John K. Roman, Race, Justifiable Homicide, AND 
Police have also singled out and overly scrutinized the lawful actions of the transgender community, from enforcing so-called "impersonation or masquerade laws" 25 and issuing disturbing the peace citations for gender nonconforming dress, ${ }^{26}$ to baselessly arresting individuals for prostitution based on transphobic assumptions about sexual behavior. ${ }^{27}$ Increasingly, as Ky Peterson, $\mathrm{CeCe} \mathrm{McDonald},{ }^{28}$ and other Black transgender victims of violence have learned, lawfully protecting oneself from violent physical assault has merely provided police another opportunity to scrutinize, over-enforce, and overcriminalize a vulnerable and marginalized community.

This Essay highlights the need for, and elusiveness of, self-defense as a viable affirmative defense for the Black transgender community and the central role law enforcement plays in this narrative. Police protection is needed but largely remains unavailable to this disproportionately victimized community, making self-defense a necessary last resort. But police over-enforcement and criminalization of this community renders self-defense an elusive tool of legal protection, especially when other institutional actors-prosecutors, judges, and juries - may harbor many of the same pernicious prejudices infecting precincts across the country.

Recent events in Brunswick, Georgia, three hours from Ky Peterson's rape and self-defensive actions, highlight the urgent need to confront this issue..$^{29} \mathrm{In}$ -

Stand Your Ground Laws: Analysis of FBI Supplementary Homicide Report Data 7 tbl.2 (2013)), https://everytownresearch.org/wp-content/uploads/sites/4/2020/07/inherent-dan ger-stand-ground-laws.pdf [https://perma.cc/7S84-G8YY] ("When white shooters kill black victims, the resulting homicides are deemed justifiable 11 times more frequently than when the shooter is Black and the victim is white.").

${ }^{25}$ Buist, supra note 15, at 885-86 (summarizing a long history of "anti-cross-dressing" laws).

${ }^{26}$ Gabriel Arkles, Correcting Race and Gender: Prison Regulation of Social Hierarchy Through Dress, 87 N.Y.U. L. REV. 859, 882 (2012) ("In 2011, Oklahoma police arrested a Black trans woman for disorderly conduct because she wore high heels and carried a purse in a public park."); see Galbreath v. City of Oklahoma City, No. CIV-11-1336-HE, 2012 WL 255734 , at $* 2$ (W.D. Okla. Jan. 27, 2012) (providing the arresting officer's account of the reasons for the arrest).

${ }^{27}$ See Buist, supra note 15, at 886 (recounting the story of Monica Jones, a Black trans woman who was arrested in 2014 in Phoenix, Arizona on suspicion of prostitution based in part on her appearance and transgender identity).

28 See Sabrina Rubin Erdely, The Transgender Crucible, Rolling Stone (July 30, 2014, 2:00 PM), https://www.rollingstone.com/culture/culture-news/the-transgender-crucible-1140 95 [https://perma.cc/UVR5-4Y35] (describing the case of a homeless transgender woman who was attacked by a group of men hurling racist and transphobic insults, defended herself with a glass bottle, stabbed and killed an attacker with a visible swastika tattoo, and was charged with second degree murder before pleading guilty to manslaughter).

${ }^{29}$ Charles M. Blow, The Killing of Ahmaud Arbery, N.Y. Times (May 6, 2020), https://www.nytimes.com/2020/05/06/opinion/ahmaud-arbery-killing.html [https://perma.cc/ H7AH-6W35] (describing the case of Ahmaud Arbery, an unarmed black man chased and shot dead by two White men during a botched "citizen's arrest" based solely on their mistaken assumption that he was an armed robbery suspect). 
deed, when a District Attorney can claim that two White men chasing and gunning down an unarmed Black man in broad daylight as part of a "citizen's arrest" was a justifiable act of self-defense, one cannot help but wonder why Ky Peterson sits in a Georgia prison today..$^{30}$

\section{THE NEED FOR SELF-PROTECTION}

This Essay posits a greater need among the Black transgender population to employ self-defense as a survival strategy for two primary reasons. First, rates of violence-including sexual violence, intimate partner violence, and murder-are far higher for this population than the national average. Second, Black transgender victims of violence cannot reliably depend on law enforcement for protection from their perpetrators. These victims who report their crimes face ambivalence, claims of dishonesty, discrimination, and violence from the very police charged with protecting them. This dual reality that Black transgender individuals are both more likely to be violently assaulted and less likely to be protected by police often makes self-defense the last available option.

\section{A. Rates of Violence}

Reliable data on transgender populations remains scarce for a variety of reasons ${ }^{31}$ but government agencies and human rights organizations uniformly report that the transgender community faces disproportionate rates of violence in the United States. ${ }^{32}$ Much of this violence involves transphobic harassment regarding gender identity and gender-based sexual violence. The National Resource Center on Domestic Violence (NRCDV) reported that, according to a 2015 U.S. Transgender Survey, 46 percent of respondents were "verbally harassed in the past year because of being transgender," 9 percent "were physical-

${ }^{30} I d$. (quoting two prosecutors who recused themselves from the case after making statements that the killing was justified, alternatively because "[a] private person may arrest an offender if the offense is committed in his presence or within his immediate knowledge," and that "[g]iven the fact that Arbery initiated the fight, at the point Arbery grabbed the shotgun, under Georgia law, McMichael was allowed to use deadly force to protect himself"). Video footage later released of the incident refutes this claim. Id.

${ }^{31}$ See FORGE, TRANSGENDER RATES OF VIOLENCE (2012), https://forge-forward .org/resourc e/rates-of-violence [https://perma.cc/QDP5-UQD9].

32 See Nat'l Res. Ctr. on Domestic Violence, Violence Against Trans and Non-Binary People, https://vawnet.org/sc/serving-trans-and-non-binary-survivors-domestic-and-sexual-viole nce/violence-against-trans-and [https://perma.cc/GUT9-WBEU]; FORGE, supra note 31; Off. for Victims of Crime, Responding to Transgender Victims of Sexual Assault: The Numbers (June 2014), https://ovc.ojp.gov/sites/g/files/xyckuh226/files/pubs/forge/sexual_number s.html [https://perma.cc/UNU3-PSQ3]; see also Carpenter \& Marshall, supra note 17, at 7 ("[T]ransgender women are at exceptionally high risk of experiencing violence and harassment, which is meted out by both private and state actors, and both in private and institutional spaces."). 
ly attacked ... because of being transgender," 47 percent had been the victim of a sexual assault, and 54 percent had experienced "intimate partner violence." ${ }^{33}$ These rates of violence are double, and in some cases triple, the commonly reported rates of sexual violence and intimate partner abuse..$^{34}$ Moreover, both NRCDV and the federal government's Office for Victims of Crime report that rates of violence in the transgender community are even higher for transgender communities of color, especially Black transgender individuals. ${ }^{35}$

Scholars examining this data have explored the multilayered discrimination facing this intersectional group. Particularly for victims of intimate partner violence (IPV), "[s]tatistics show that Black women suffer from intimate partner violence at a higher rate than white women ... [and] that trans people are at an increased risk for intimate partner violence" within that group. ${ }^{36}$ This disproportionate impact is reflected in lethal IPV cases as well:

[m]ore than [50] percent of female homicide victims between the ages of eighteen and forty-four are killed by an intimate partner, and Black women are killed at a rate almost three times that of white women. [Within that group,] [t]ransgender persons are also at an increased risk for intimate partner violence because of transphobia within their intimate relationships. ${ }^{37}$

Some scholars have explained that these increased rates of IPV and sexual violence reflect a desire to control and enforce gender norms within relationships ${ }^{38}$ and vulnerability for transgender people who cannot conform to these gender stereotypes. ${ }^{39}$

There certainly exists room at the margins to quibble with the accuracy of these quoted statistics because little consistent demographic data has been col-

${ }^{33}$ Nat'l Res. Ctr. on Domestic Violence, supra note 32.

${ }^{34}$ Off. for Victims of Crime, supra note 32; see also Carpenter \& Marshall, supra note 17 (nothing that Black transgender women "experience domestic violence at extraordinary rates").

${ }^{35}$ Off. for Victims of Crime, supra note 32; see also TAYLOR N.T. Brown \& JODY L. Herman, Intimate Partner Violence and Sexual Abuse Among LGBT People: A REVIEW OF Existing ReSEARCH 3, 5, 14 (2015); Buist, supra note 15, at 877 (“"[T]he transgender community ... faces unheard of rates of violence, especially transgender women of color. Transgender women of color are murdered in the United States at rates that continue to increase."); Carpenter \& Marshall, supra note 17 ("Every year in recent history has seen the murder of scores of transgender women of color, most notably Black transgender women.").

${ }^{36}$ Ijoma, supra note 1, at 255-56; see also NAT'L CTR. FOR INJ. PREVENTION \& CONTROL, National Intimate Partner and Sexual Violence Survey: 2010 Summary RePort 39 (2011) (finding that "rape, physical violence, and/or stalking by an intimate partner" is more prevalent among Black women than white women).

${ }^{37}$ Ijoma, supra note 1, at 260 (footnote omitted); see also Leigh Goodmark, Transgender People, Intimate Partner Abuse, and the Legal System, 48 HARV. C.R.-C.L. L. REV. 51, 9193 (2013).

38 Goodmark, supra note 37, at 94.

${ }^{39} \mathrm{Id}$. 
lected about this population. ${ }^{40}$ But legal observers and human rights groups agree that these shocking statistics are almost certainly underreported. ${ }^{41}$

\section{B. Police (Non)responsiveness}

Given the reality that Black transgender individuals face disproportionate rates of violence, "one would reasonably conclude that law enforcement ought to be doing everything in their power to protect transgender women [and men] from violence at the hands of private actors. However, ... the converse appears to be true." ${ }^{\prime 2}$ Disturbing anecdotal and empirical evidence suggests police respond to transgender victims with a mixture of ambivalence, distrust, transphobic discrimination, and violence.

Much of this troubling official response appears linked to regressive attitudes about gender normativity. For example, IPV "is just as prevalent if not more prevalent in same-sex relationships, yet the enforcement of criminal law regarding arrests of such offenders is [more] limited" than in opposite-sex relationships..$^{43}$ One explanation proffered by scholars and police themselves is that "officers are more likely to take heterosexual IPV more seriously and see straight male offenders as the more serious perpetrators," in part because of beliefs about the inherent fragility of women in opposite-sex relationships. ${ }^{44}$

More broadly, transgender victims of crime "report a high frequency of negative interactions with law enforcement," both when reporting criminal ac-

40 The transgender community, and the broader LGBTQ+ community, has fought for years even to be officially counted by government bureaus. See Alex Ronan, How Big Is the Transgender Population?, CuT (June 11, 2015), https://www.thecut.com/2015/06/how-bigis-the-transgender-population.html [https://perma.cc/2XGC-R6RL] ("There's no national data on the size of the transgender population because official record collectors like the United States Census Bureau don't ask about gender identity."); Mary Emily O'Hara, LGBTQ Americans Won't Be Counted in 2020 U.S. Census After All, NBC NEws (Mar. 29, 2017, 10:27 AM), https://www.nbcnews.com/feature/nbc-out/lgbtq-americans-won-t-be-cou nted-2020-u-s-census-n739911 [https://perma.cc/Z5MS-YVTC]; ANDREW R. FLORES ET AL., How Many Adults Identify as TRAnSgender in the United States? 2 (2016), https://williamsinstitute.law.ucla.edu/publications/trans-adults-united-states [https://perma.cc /YX86-A48D] ("Population-based surveys ... rarely ask questions to identify transgender people ....").

${ }^{41}$ A National Epidemic: Fatal Anti-Transgender Violence in the United States in 2019, Hum. RTS. CAMPAIGN (Nov. 2019), https://www.hrc.org/resources/a-national-epidemic-fatalanti-trans-violence-in-the-united-states-in-2019 [https://perma.cc/84JD-UH6N] (explaining that rates of violence against the transgender community "very likely undercount the number of transgender and gender non-conforming people who [are] killed in the United States... often because authorities, journalists and/or family members refuse to acknowledge [the victim's] gender correctly").

${ }^{42}$ Carpenter \& Marshall, supra note 17, at 9, 12; see also AMNESTY INT'L, supra note 19, at 65,71 .

${ }^{43}$ Buist, supra note 15 , at 883; AdAm M. Messinger, LGBTQ Intimate Partner

Violence: Lessons For Policy, PRACTICE, AND RESEARCH 5 (2017).

${ }^{44}$ Buist, supra note 15, at 884. 
tivity and when being approached by police. ${ }^{45}$ Nearly one-third of all transgender victim respondents report "being treated in a generally disrespectful way by police," while 47 percent of Black transgender victims report being "disrespected by police." 46

Much of this reported disrespect takes the form of disbelieving or discrediting transgender victim stories of violence. While victims of sexual violence and IPV across the board-particularly victims identifying as female-suffer from the "credibility discount" by an ambivalent and skeptical criminal legal system, ${ }^{47}$ transgender violence victims often confront the unique false stereotype that they are inherently "deceitful." ${ }^{48}$ For decades, many states expressly mandated binary gender conformity under threat of punishment, criminalizing the "impersonation" of a gender not in conformance with one's assigned birth sex. 49 "These [anti-cross dressing] or masquerade laws have contributed to the lie that queer folks, ... especially transgender folks, are deceptive by nature and not to be trusted, which in turn exacerbates the distrust between law enforcement and the queer community." 50

This mutual distrust is reflected not only in police skepticism of transgender victims but in "[1]aw enforcement's pervasive profiling of transgender women, particularly those of color, as sex workers." ${ }^{51}$ Transgender women "overwhelmingly report [this] very specific problem," noting that police subject them to "aggressive, often abusive, policing practices based upon

${ }^{45}$ Carpenter \& Marshall, supra note 17, at 13; see also Buist, supra note 15, at 886; ERIN Fitzgerald et al., Meaningful Work: Transgender Experiences in the Sex Trade 5 (2015).

${ }^{46}$ Carpenter \& Marshall, supra note 17, at 13.

${ }^{47}$ Deborah Tuerkheimer, Incredible Women: Sexual Violence and the Credibility Discount, 166 U. PA. L. REV. 1, 57 (2017) (describing the "credibility discount," that is, "the legal rules that once formally embedded skepticism of rape complaints, and ... [the] contemporary outlet for this skepticism in police and prosecutorial responses to sexual violence").

${ }^{48}$ Dylan Vade, Expanding Gender and Expanding the Law: Toward a Social and Legal Conceptualization of Gender That Is More Inclusive of Transgender People, 11 MicH. J. GENDER \& L. 253, 263 (2005) ("[T]he sex-gender distinction plays into a belief that transgender people are deceitful, a belief that can cost transgender people their lives."); Cynthia Lee \& Peter Kwan, The Trans Panic Defense: Masculinity, Heteronormativity, and the Murder of Transgender Women, 66 Hastings L.J. 77, 114 (2014) (explaining that the trans panic defense rests on the premise that a transgender woman is being deceitful if she does not disclose her biological sex); Cynthia Lee, The Trans Panic Defense Revisited, 57 AM. CRIM. L. REV. 1411, 1444 (2020) (same).

49 See Buist, supra note 15, at 885; Lauren Bishop, Gender and Sex Designations for Identification Purposes: A Discussion on Inclusive Documentation for a Less Assimilationist Society, 30 WiS. J.L., GENDER \& SOC’Y 131, 150 (2015) (“[P]ast sumptuary laws . . gave police the authority to arrest anyone found 'impersonating another gender' by not wearing 'gender appropriate clothing.' ").

50 Buist, supra note 15, at 885-86 ("Police have long-viewed the queer community not as a group in need of understanding and support, but in need of surveillance and punishment.").

${ }^{51}$ Carpenter \& Marshall, supra note 17, at 5-6 (footnote omitted); see FITZGERALD ET AL., supra note 45 , at 17. 
law enforcement's perception that they are universally and perpetually engaged in sex work." 52 "This phenomenon," wherein officers "stop, harass, and demand identification from transgender women," command that they disperse, and "arrest them for low-level [quality of life] offenses tied to suspicions of prostitution ... is sufficiently widespread that the transgender community has given it the colloquial label "walking while trans." "'53 This specific form of police harassment also disproportionately affects the Black transgender community, with 38 percent of these individuals reporting profile-based harassment, compared with 22 percent of all transgender individuals..$^{54}$

Many vaguely worded local ordinances criminalizing the "manifestation" of an intent to engage in prostitution, which often turn on subjective factors such as how often a person stops and engages passersby in conversation, only exacerbate this profiling. ${ }^{55}$ As Monica Jones, a Black transgender student at Arizona State University learned, "[t]he difference between 'innocent' and 'criminal' behavior often comes down to how a person looks." ${ }^{56}$ Jones reported being repeatedly harassed by police and suspected of solicitation on four occasions, including while "walking to the grocery store" and "visiting with a friend on the sidewalk," before finally being arrested for manifesting an intent to engage in prostitution in May 2014..$^{57}$ Despite neither engaging in nor harboring any intent to engage in sex work, ${ }^{58}$ Jones suffered the dual discrimination of being suspected of criminal activity because of her race ${ }^{59}$ and being suspected of "deceitful" and "hypersexual" ${ }^{60}$ conduct because of her transgender identity.

\section{Self-Defense as a Last Resort}

Police skepticism, harassment, and profiling of Black transgender individuals "significantly erodes the level of trust and comfort" this population feels "with respect to law enforcement," which in turn dramatically suppresses crime reporting among this group. ${ }^{61}$ This distrust also makes self-help measures, in-

52 Carpenter \& Marshall, supra note 17, at 13-14.

53 Id. at 6.

${ }^{54} \mathrm{Id}$. at 13 .

${ }^{55}$ Chase Strangio, Arrested for Walking While Trans: An Interview with Monica Jones, ACLU CRIM.L. REFORM BLOG (Apr. 2, 2014, 11:19 AM), https://www .aclu.org/blog/crimina l-law-reform/arrested-walking-while-trans-interview-monica-jones [https://perma.cc/N7EU7UUA].

${ }^{56} I d$.

${ }^{57} \mathrm{Id}$.

58 See id.

${ }^{59} \mathrm{Id}$.

60 See Ijoma, supra note 1, at 273, 283.

${ }^{61}$ Carpenter \& Marshall, supra note 17, at 16; see also JAMIE M. GRANT ET AL., NAT'L GAY \& Lesbian TAsk Force \& Nat'L CTR. For Transgender Equal., InJustice at Every Turn: A Report of the National Transgender Discrimination Survey 162 (2011) 
cluding violent self-defense, a more attractive option for this vulnerable intersectional population. ${ }^{62}$

But this calculation to take self-help measures is driven by more than preference. It is one of survival. Sexual violence and harassment against transgender women, especially Black transgender women, "is especially pervasive in the endemically violent and highly gender-segregated institutions that make up the American criminal justice system." ${ }^{63}$ When Black transgender victims interact with law enforcement, either voluntarily or involuntarily, they run the very real risk that they will be profiled, arrested and charged, and placed in a prison system where they disproportionately "suffer unusually brutal hardships." ${ }^{64}$ These binary, gender-segregated prisons make transgender women in particular extraordinarily vulnerable to attacks by men incarcerated in the same facility. In one recent case, a transgender woman was arrested "regarding something minor. Due to my gender being marked male, I was put in with the men. Within [fifteen] minutes, I was raped by [three] different men." ${ }^{65}$

In short, the threat of police harassment, coupled with the threat of sexual violence in prison, compels many Black transgender victims to believe that police "may be more dangerous than perpetrators of violence." ${ }^{66}$ As a result, these victims may choose to remain with abusers rather than report them to the police, and when necessary, protect themselves through self-defense as the last and only resort.

\section{The Elusiveness of SELF-Defense}

Both the over-victimization of Black transgender individuals by private actors and the under-protection of these individuals by law enforcement compel a greater need for self-help measures. As the experiences of Ky Peterson and $\mathrm{CeCe} \mathrm{McDonald}$ illustrate, sometimes these necessary self-help measures in-

("Police harassment and assault had an apparent deterrent effect on respondents' willingness to seek out help from law enforcement.").

${ }^{62}$ See Buist, supra note 15 , at 878,885 ("[Q]ueer criminology studies the persistent distrust that the LGBTQ+ community has of police.... [E]xisting studies ... continue to reveal queer folks' distrust of police and in turn polices' distrust of queer folks.").

${ }_{63}$ Carpenter \& Marshall, supra note 17, at 7; see also id. at 10 n.21 ("[T]ransgender inmates in American prisons who have not undergone sex reassignment surgery 'are generally classified according to their birth sex for purposes of prison housing, regardless of how long they may have lived as a member of the other gender ....", (quoting Chapter Three: Classification and Housing of Transgender Inmates in American Prisons, 127 HARV. L. REV. 1746, $1748(2014)))$.

${ }^{64}$ Id. at 7.

${ }^{65} I d$. at 11 (citing GRANT ET AL., supra note 61, at 168).

${ }^{66} \mathrm{Id}$. at 9; see also Ijoma, supra note 1, at 286 ("[P]olice arrests of transgender people who report intimate partner violence and sexual assault are frequent."); ANDREA J. RITCHIE, Invisible No More: Police Violence Against Black Women and Women of Color 191 (2017) ("Advocates also told us that, where domestic violence against transgender women is concerned, officers often laugh, or say, 'You're a man, too. You can handle yourself ....."). 
volve lethal self-defense. At common law, states recognized as legitimateindeed, justified - such killing in self-defense when reasonably necessary to repel an imminent, proportional attack. More recently, states have codified broad expansions of this affirmative defense and relaxed its narrow application, authorizing citizens to "stand their ground" and eliminating the duty to retreat from conflict even where it is possible to do so.

This expansion should be good news to Black transgender victims forced to defend themselves. Unfortunately, many of the same stereotypes corroding transgender victims' interactions with law enforcement similarly infect the prosecutors, judges, and juries assessing the validity of their self-defense claims. The end result is a system that both refuses to protect this vulnerable population from private violence and then punishes them for lawfully exercising their right to protect themselves.

\section{A. Common Law Self-Defense}

The intentional killing of another person is regarded as the most morally blameworthy, and thus most severely punished, act in criminal law. ${ }^{67}$ As a result, "[t]he legal principles that permit the use of deadly force in self-defense present a very limited exception to the rule that killing is illegal." 68 Affirmative self-defense provides a legal justification to homicide, communicating society's moral judgment that the violent act itself was not just "understandable" but actually "desirable." ${ }^{69}$

Not surprisingly, this legal justification to kill has traditionally been narrowly defined and applied. At common law, a person could only use force in self-defense if she honestly and reasonably believed that she was in imminent danger, force was necessary to avoid the danger, and the force used was proportional to the threat. ${ }^{70 ~ " T h e s e ~ f o u r ~ e l e m e n t s-i m m i n e n c e ~ o f ~ t h r e a t, ~ n e c e s s i t y, ~}$

${ }^{67}$ State v. Brown, 931 P.2d 69, 72 (N.M. 1996) ("First-degree murder is reserved for the most blameworthy or 'the most heinous and reprehensible' class of homicides ...." (quoting State v. Garcia, 837 P.2d 862, 865 (N.M. 1992))); see also Enmund v. Florida, 458 U.S. 782, 796-97 (1982) (holding that imposing the death penalty for felony murder violates the Eighth Amendment when the defendant does not kill, attempt to kill, or intend to kill the victim); Kennedy v. Louisiana, 554 U.S. 407, 438 (2008) (holding that imposing the death penalty for the rape of a child violates the Eighth Amendment); Stephanie N. O'Banion, Dying in Detention: Are Life Without Parole Sentences for Juvenile Non-Homicide Offenders Always Unconstitutionally Cruel and Unusual Punishment Under the Eighth Amendment?, 38 U. DAYTON L. REv. 449, 463 ("[I]t is the culpability of the offender . . that causes society to consider a homicide crime more morally blameworthy than all other crimes.”).

68 Rolnick, supra note 23, at 1658.

${ }^{69} \mathrm{Id}$.

702 Wharton's CRiminal LAW $\S 127$ (15th ed. 2018) (a person may kill in self-defense if "he reasonably believes that he is in imminent danger of losing his life or suffering great bodily harm"). 
proportionality, and reasonableness - form the legal bounds of traditional selfdefense doctrine." ${ }^{\prime 1}$

Two of these elements - necessity and reasonableness - require brief further discussion for purposes of this Essay. Necessity requires that the use of force be the only available option; if a safe retreat or de-escalation is available, force may not be used..$^{72}$ The one exception to that requirement exists in the home, where in "defense of habitation" a person need not retreat to use force to defend oneself. ${ }^{73}$ This "castle doctrine" has existed in English common law for hundreds of years and until recently was strictly confined to the home. ${ }^{74}$ However, as discussed below, state legislatures have enacted a series of laws increasingly allowing the use of force in public places even when a safe retreat option exists. These so-called "Stand Your Ground" laws have extended the castle doctrine to virtually any private or public space in society. ${ }^{75}$

As for reasonableness, the adjudication of this element presents challenging problems fraught not only with the inherent subjectivity of the shooter's mental state but with larger societal issues related to race, gender, age, and other demographic markers. "Reasonableness" has long been viewed from the perspective of the reasonable White man in American law and culture, and what is collectively viewed as "reasonable" may very well have implicit or explicit racist, sexist, and gender normative contours, both for the shooter and for the "victim." 76 Many scholars have critiqued this reasonableness requirement as inherently infected with society's collective implicit bias that it is reasonable to assess dark-skinned individuals as more threatening and to act accordingly in self-defensive response. ${ }^{77}$ But as discussed below, this bias works in reverse.

71 Rolnick, supra note 23, at 1659.

72 See George P. Fletcher, Basic Concepts of Criminal Law 134-36 (1998).

73 See State v. Kuhns, 817 S.E.2d 828, 830 (N.C. Ct. App. 2018) (““[A] man’s house, however humble, is his castle, and his castle he is entitled to protect against invasion[.]' ... Commonly known as the 'castle doctrine,' the defense of habitation is 'based on the theory that if a person is bound to become a fugitive from her own home, there would be no refuge for her anywhere in the world." " (citations omitted) (first quoting State v. Gray, 77 S.E. 833, 835 (1913); then quoting State v. Stevenson, 344 S.E.2d 334, 335 (1986))).

${ }^{74}$ Id.; see Conner v. State, 361 So. 2d 774, 775 (Fla. Dist. Ct. App. 1978) ("The castle doctrine is of ancient origin ....").

75 See infra Section II.B.

76 See Lee, Making Race Salient, supra note 23, at 1584-85 (observing that implicit bias from the dominant White majority affects a jury's reasonableness calculus: "If most individuals would be more likely to 'see' a weapon in the hands of an unarmed Black person than in the hands of an unarmed White person ... then jurors in self-defense cases may also be more likely to find that an individual who says he shot an unarmed Black person in selfdefense ... acted reasonably, even if he was mistaken.”).

77 L. Song Richardson \& Phillip Atiba Goff, Self-Defense and the Suspicion Heuristic, 98 IowA L. REV. 293, 310 (2012) ("Blacks serve as our mental prototype (i.e., stereotype) for the violent street criminal."); id. at 314 ("When the person being judged fits a criminal stereotype, the suspicion heuristic can cause the actor more easily to believe honestly-but mistakenly - that the person poses a threat and that deadly force is necessary ....”). 
The same stereotype mythologizing racial minorities as inherently violent also calls into question the "reasonableness" of violent self-defensive actions taken by those same minorities, even if otherwise necessary and lawful.

\section{B. Stand Your Ground}

In the last two decades, states have expanded the centuries-old "core" selfdefense doctrine through a series of legislative enactments collectively referred to as "Stand Your Ground" laws. ${ }^{78}$ These laws remove any duty to retreat when a person feels threatened and permit the use of deadly force in public if the person reasonably believes it is necessary to prevent imminent death or great bodily harm. ${ }^{79}$

Stand Your Ground laws upend traditional self-defense doctrine in numerous ways. Under traditional self-defense law, a person can use force to defend themselves anywhere, but when they are outside their home they cannot use force likely to kill or seriously injure someone if there is a safe way to avoid doing so. ${ }^{80}$ This traditional law respects both a person's right to self-defense and the sanctity of human life by requiring someone to avoid taking a life if a clear and safe alternative exists. ${ }^{81}$

Conversely, the well-established castle doctrine exception allows a person inside their home to defend themselves with force even if they could have safely walked away. ${ }^{82}$ Stand Your Ground laws remove the duty to retreat by allowing people to shoot to kill in public even if a clear and safe alternative exists. At least thirty-five jurisdictions have some version of Stand Your Ground, either through legislative enactment or judicial order, while another three have expanded the castle doctrine. ${ }^{83}$

In addition to expanding the castle doctrine to apply broadly anywhere in public, Stand Your Ground laws significantly relax the requirements of imminence and proportionality, necessarily broadening what the law will recognize as a justified homicide. Under traditional self-defense law, "a defendant must demonstrate that the threatened harm to which he is reacting is imminent," un-

78 See Lave, supra note 11.

79 See Aya Gruber, Race to Incarcerate: Punitive Impulse and the Bid to Repeal Stand Your Ground, 68 U. MiA. L. REV. 961, 962 (2014).

${ }^{80}$ See Lave, supra note 11 (analyzing the difference between "Stand Your Ground [and] a more traditional self-defense law"); Cynthia V. Ward, "Stand Your Ground" and SelfDefense, 42 AM. J. CRIM. L. 89, 93-100 (2015) (discussing the historical and legal development of the traditional self-defense rule in criminal law).

${ }^{81}$ See Stand Your Ground, supra note 12.

${ }^{82}$ Catherine L. Carpenter, Of the Enemy Within, the Castle Doctrine, and Self-Defense, 86 MARQ. L. REv. 653, 667 (2003) ("In the case of defense of habitation, the Castle Doctrine allows the resident to stand ground and use deadly force against the intruder to protect the sanctity of the home from the attempted atrocious felony because the duty to retreat would be incompatible with the goal of preventing the commission of the felony.").

${ }^{83}$ Stand Your Ground, supra note 12. 
less the defendant is confronted with an intruder in his own home ${ }^{84}$ But by expanding this "defense of habitation" rule to all public spaces, Stand Your Ground laws create "a presumption of imminent threat when an intruder tries to break into an unoccupied building, car, or a boat." ${ }^{85}$ Some states do not even require the intruder to be actively intruding, but only near the structure, stretching the meaning of the word "imminent" to strain credulity. ${ }^{86}$

A growing chorus of scholars and activists harshly criticize Stand Your Ground laws, pointing to damning empirical evidence significantly correlating the laws with increased violent crime. ${ }^{87}$ It is indisputable that these laws "are associated with higher rates of homicides." 88 A 2012 study by researchers at Texas A\&M found that Stand Your Ground jurisdictions saw a significant increase in homicide rates, with an average of more than 600 additional homicides per year. ${ }^{89}$

Moreover, Stand Your Ground laws have a clear disproportionate impact on communities of color..$^{90}$ In advocating for the repeal of Stand Your Ground laws, the advocacy group Everytown for Gun Safety noted that "[w]hen white shooters kill Black victims, the resulting homicides are deemed justifiable [eleven] times more frequently than when the shooter is Black and the victim is white." ${ }^{91}$ Therefore, the death of a minority individual in a Stand Your Ground case is "half as likely to lead to a conviction, compared to cases with white victims." ${ }^{22}$ Similarly, the American Bar Association has highlighted that Stand Your Ground laws exacerbate existing racial tensions and "perpetuate[] a foolish bravado of those who feel a bold security when they have a gun in their hand, and it exonerates an arrogance and/or ignorance." ${ }^{93}$

Researchers have also shown that implicit bias and cultural misperceptions of racial minorities as "more violent" or "more aggressive" exacerbate the disproportionate impact of Stand Your Ground laws. ${ }^{94}$ Many scholars have noted the importance of race and racial stereotypes as public policy considerations when considering whether to repeal Stand Your Ground laws, explaining that

${ }^{84}$ Rolnick, supra note 23, at 1679, 1680.

85 Id. at 1681 .

${ }^{86} I d$. at $1681,1685,1688,1690$.

87 See, e.g., Lave, supra note 11, at 856; Gruber, supra note 79, at 964; Shawn E. Fields, Weaponized Racial Fear, 93 Tul. L. REv. 931, 987 (2019) (criticizing Stand Your Ground laws as a form of state sanction for racially fearful "vigilantes" to police the color line in public).

${ }^{88}$ A.B.A., supra note 24, at 6, 11-14 (2015) (citing data from four nationwide surveys).

${ }^{89} I d$. at 11.

90 Id. at 24-26.

91 The Inherent Danger of Stand Your Ground Laws, supra, note 24.

${ }_{92}$ Id.

93 A.B.A., supra note 24, at 24 (quoting Leonard Leach, Reverend, Mt. Hebron Missionary Baptist Church).

${ }^{94}$ Id. 
cross-racial and cross-cultural fears and perceptions can unfairly impact the reasonableness prong in a justifiable homicide analysis. ${ }^{95}$

These critics focus primarily on the detrimental impacts Stand Your Ground laws have on Black people and other persons of color as unfair targets of lethal violence from armed vigilantes. ${ }^{96}$ As one attorney representing the family of a Black victim of a purported Stand Your Ground homicide observed, "minority communities are deathly afraid that Stand Your Ground law sits sideby-side with racial profiling; the ticket to vigilante justice." ${ }^{97}$ But these expanded legal protections for self-defense measures, troubling as they are, should in theory at least provide a more accessible avenue to the type of legal sanction vulnerable groups like the Black transgender community need. In fact, conservative lobbying groups like the National Rifle Association (NRA) and American Legislative Exchange Council (ALEC) made this argument when first proposing model Stand Your Ground legislation.98 "According to the NRA, this type of legislation empowers innocent victims who have appealed to the court system for help, while recognizing that the process for approving an application for a gun permit may take too long for some victims." 99

\section{Structural Barriers to Self-Defense Protection}

Rather than providing greater protections for vulnerable victims, the protection of Stand Your Ground laws is unevenly available for minority victim populations, resulting in "a disparate impact on Black women and trans people of color." 100 Whether under traditional or expanded self-defense doctrine, persistent biases in the criminal legal system about what makes a person a "victim" virtually foreclose affirmative self-defense for the Black transgender community. These pernicious biases include racist tropes about the inherent criminality of Black people, the transphobic beliefs about the community's purported deceitfulness and hypersexuality, and this intersectional group's inability to claim the discredited mantle of the "perfect victim."

\section{Racist Tropes}

Scholars and historians have convincingly demonstrated that the racial apartheid defining much of this nation's history was supported by racist fear-

95 See id.

96 See, e.g., Fields, supra note 87, at 985, 988.

97 A.B.A., supra note 24, at 24.

98 Ijoma, supra note 1, at 256-57, 263 ("When the first version of a Stand-Your-Ground law was proposed in Florida, the NRA argued that laws expanding self-defense were designed to protect women ... advocating for gun ownership as a solution to intimate partner violence ('IVP') and other various forms of gendered violence.").

${ }^{99}$ Id. at 258.

${ }^{100}$ Id. at 255, 288; see also Fields, supra note 87, at 988; Lave, supra note 11, at 843. 
mongering warning White America about the inherent criminality and violent propensities of Black people, particularly Black men. ${ }^{101}$ Myths of the "black bogeyman" 102 have endured for centuries and taken many forms - from the "rebellious Negro,"103 to the "black brute" rapist, ${ }^{104}$ to the "super predator." 105 These racist tropes of a Black criminal subclass are now so ingrained in the fabric of American society that science long ago confirmed the existence of a pervasive, unconscious, and largely automatic bias against dark-skinned individuals as more hostile, criminal, and prone to violence. ${ }^{106}$ These biases infect nearly everyone. ${ }^{107}$

101 Fran Lisa Buntman, Race, Reputation, and the Supreme Court: Valuing Blackness and Whiteness, 56 U. MiA. L. REV. 1, 1 (2001) ("In the United States, being black . . has long been seen as a sign of criminality, or at least criminal propensity."); Paul Finkelman, The Crime of Color, 67 Tul. L. REv. 2063, 2070, 2072, 2077, 2090-91, 2093 (1993) (tracing the history of "blackness" as synonymous with crime to early court decisions justifying slavery because of the inherent criminality of black men).

102 Laura T. Fishman, The Black Bogeyman and White Self-Righteousness, in IMAGES OF COLOR, IMAGES OF CRIME 109, 113 (1998).

103 Bryan Adamson, "Thugs," "Crooks," and "Rebellious Negroes": Racist and Racialized Media Coverage of Michael Brown and the Ferguson Demonstrations, 32 HaRv. J. ON RACIAL \& ETHNIC JUST. 189, 226-27 (2016) (connecting the centuries-old "rebellious Negro trope" to current coverage of unarmed black men killed by police officers).

104 R.A. Lenhardt, Understanding the Mark: Race, Stigma, and Equality in Context, 79 N.Y.U. L. REV. 803, 859-60 (2004) (describing the stereotype of "the black beast, a violent brute with an unusually powerful sexual appetite for white women who was completely devoid of humanity"); Jasmine B. Gonzales Rose, Racial Character Evidence in Police Killing Cases, 2018 WIS. L. REv. 369, 408 (2018) (“The 'black brute' stereotype may be one of the most enduring in this nation's history and persists even today." (quoting Ryan P. Alford, Appellate Review of Racist Summations: Redeeming the Promise of Searching Analysis, 11 Mich. J. RACE \& L. 325, 346 (2006))); Barbara Holden-Smith, Lynching, Federalism, and the Intersection of Race and Gender in the Progressive Era, 8 YALE J.L. \& FEMINISM 31, 59 (1996) (recalling how the "Southern myth of the 'black-beast' rapist justified lynching" in the post-Reconstruction South).

105 Robert J. Smith \& Zoë Robinson, Constitutional Liberty and the Progression of Punishment, 102 CORNELl L. Rev. 413, 425 (2017) (tracing the genesis of the "super-predators" myth to a warning by Professor John Dilulio "of a coming 'breed' of juvenile offenders" who are "fatherless, Godless, and jobless" and who "kill, rape, [and] maim, without giving it a second thought"); Robert Mackey, 1996: Hillary Clinton on 'Superpredators', C-SPAN (Feb. 25, 2016), https://www.c-span.org/video/?c4582473/hillary-clinton-super-predators1996 [https://perma.cc/PA5D-V6MY] (video of then-First Lady Hillary Rodham Clinton warning of "the kinds of kids that are called super-predators. No conscience, no empathy. We can talk about why they ended up that way, but first we have to bring them to heel.").

106 L. Song Richardson \& Phillip Atiba Goff, Implicit Racial Bias in Public Defender Triage, 122 YALE L.J. 2626, 2629-31 (2013) (summarizing science of implicit bias and the widely-held implicit stereotype of "blacks as violent, hostile, aggressive and dangerous"); Rachel D. Godsil \& L. Song Richardson, Racial Anxiety, 102 Iowa L. REv. 2235, 2238-45 (2017) (connecting implicit racial bias to systemic "racial anxiety" in interracial interactions).

107 Jerry Kang \& Mahzarin R. Banaji, Fair Measures: A Behavioral Realist Revision of "Affirmative Action," 94 CALIF. L. REV. 1063, 1080 (2006) (“[I]mplicit bias . . is pervasive but diffuse, consequential but unintended, ubiquitous but invisible."); L. Song Richardson, Po- 
These racist tropes undergird not only the unjust targeting of innocent Black people as criminals but work to deny genuine Black victims their status as such. Empirical data overwhelmingly demonstrate that police, prosecutors, judges, and juries are far less likely to believe the claims of Black victims than White victims. ${ }^{108}$ This credibility discount in turn adversely affects those Black victims who resort to lawful self-defense, who have their affirmative selfdefense claims rejected as much as ten times more frequently than similar claims by White victims. ${ }^{109}$

Much of the "black criminality" myth has been directed at Black men, but the unique rejection of claims by Black female victims of sexual and partner abuse can inform the experience of the Black transgender community as well, where significant overlap exists in the types of violence suffered. Black women are physically and sexually assaulted by intimate partners at higher rates than women of other races, but "cultural stereotypes and portrayals of the 'angry' and 'independent' Black woman have contributed to the perception that Black girls and women need 'less protection' than other women, especially white women." 110 This "myth of the angry and lascivious Black woman" 111 delegitimizes her fear in the White normative mainstream because such a woman neither fits the model of the fragile and weak victim nor "needs" the protection of society.

The Black female experience intersects with the Black transgender experience in another important way because both groups "have been depicted as promiscuous and hypersexual." 112 Although both groups are subjected to sexual violence at rates two to three times that of the national average, the "white normative view that Black women are 'less credible' victims of rape, and other

lice Efficiency and the Fourth Amendment, 87 IND. L.J. 1143, 1169 (2012) ("[I]mplicit biases are ubiquitous, [but] they are also malleable.").

108 See Rolnick, supra note 23, at 1654-55 (summarizing federal and private studies showing that Black criminal defendants are far less likely to successfully bring an affirmative selfdefense claim than their White criminal defendant counterparts); Tuerkheimer, supra note 47 at 5-6 (observing that the "credibility discount" is felt more severely among Black women and other intersectional marginalized groups).

109 Rolnick, supra note 23, at 1654.

110 Ijoma, supra note 1, at 273 (quoting REBECCA EPSTEIN ET Al., GiRLS INTERRUPTED: The ERASURE OF BLACK GIRLS' CHILDHOOD 8, https://www.law.georgetown.edu/poverty-inequali ty-center/wp-content/uploads/sites/14/2017/08/girlhood-interrupted.pdf [https://perma.cc/RJ D6-TLW6]).

111 Id. at 270 .

112 Id. at 273 \& n.115 ("explaining that 'mainstream attitudes' negated the victimization of Black women who were raped and sexually assaulted because of 'ruinous myths about [B]lack women's libidinous sexual proclivities" " (citing Kali Nicole Gross, African American Women, Mass Incarceration, and the Politics of Protection, 102 J. AM. Hist. 25, 26 (2015)). 
types of violence" permeates the criminal legal system. ${ }^{113}$ These views of Black women as angry, hypersexual, and promiscuous also delegitimize their valid claims of self-defense before a jury, which is less likely to see a victim lawfully standing her ground to protect herself and more likely to see a violent, uncontrollable criminal lashing out in rage.

\section{Transphobic Myths}

In addition to the institutional distrust of Black people as inherently violent and Black women as angry and hypersexual, official actors portray transgender victims as "inherently deceitful and deceptive because of their inability to conform to socially constructed gender norms." 114 This myth adversely impacts transgender victims' interactions with police, who skeptically refuse to offer protection. ${ }^{115}$ But it also works to deny them otherwise available affirmative self-defense claims in criminal proceedings when transgender victims of violence protect themselves "because the prosecution-employing transphobic language and traditional gender norms - successfully portrays them as untrustworthy." 116

This denial of affirmative self-defense protection exists particularly "[i]n cases involving transgender people who kill in response to abuse or sexual assault." 117 Cisgender judges and juries often refuse or cannot "accept transgender people as victims of gendered crimes" like rape or IPV, instead questioning the legitimacy of such claims. ${ }^{118}$ The same skepticism greeting transgender men and women as "bad victims" when reporting abuse to police also affects them in the courtroom:

[s]ome judges are skeptical of gender-based claims of violence by transgender litigants, insisting that because a transgender woman is not "biologically female" in the traditional sense, the abuse must instead be mutual violence within a same-sex relationship. Others have suggested that a claim of abuse is not credible because, by virtue of hir gender, the petitioner should be able to protect hirself. ${ }^{119}$

This reality confirms the underlying thesis of this Essay: transgender people, especially transgender people of color, are treated by the criminal legal system as if they are neither deserving of protection nor self-defense. Black

${ }^{113}$ Id. at 274 (quoting Carolyn West, Black Women and Intimate Partner Violence: New Directions for Research, 19 J. INTERPERSONAL VIOLENCE 1487, 1491 (2004)).

114 Id. at 283; see Goodmark, supra note 37, at 73.

115 Carpenter \& Marshall, supra note 17, at 17.

116 Ijoma, supra note 1, at 284 (citing JoEy L. Mogul ET AL., QUeER (IN)Justice: The Criminalization of LGBT People IN THE United States 71-75 (2011)).

117 Id. at 285.

$118 I d$.

119 Goodmark, supra note 37, at 89 (footnote omitted) (utilizing the gender-neutral pronouns "hir" and "hirself" often preferred by transgender and nonbinary individuals). 
transgender victims are both excluded from state forms of legal protection and yet punished under the same systems. Rather than providing a much-needed pathway to self-protection, Stand Your Ground legislation is but an example of this under-protective, over-punitive reality. Federal homicide data over a tenyear period revealed that "killings of Black people by White people were ruled justified 35 [percent] of the time," while "[k]illings of White people by Black people were ruled justifiable in only 3 [percent] of cases." 120 Further, Black on White homicides were the least likely of over a dozen demographic combinations to be deemed justified, while a study by the Marshall Project concluded that "killings of Black men by White people ... were eight times more likely to be found justifiable than any other combination." 21

Similarly reliable data including the experience of transgender individuals is scarce, but comparing the normative experiences of transgender victims and defendants suggests similarly shocking treatment. Black transgender individuals like Ky Peterson are denied the ability even to raise a valid Stand Your Ground defense in Georgia solely because of persistent transphobic attitudes denying transgender individuals "victim" status. ${ }^{122}$ In contrast, dozens of (mostly White) men have successfully raised the so-called "trans panic" defense to justify or mitigate the blame of killing a transgender individual, solely on the theory that discovery of one's transgender identity can reasonably compel angry, violent reaction, including murder. ${ }^{123}$

\section{3. "The Perfect Victim"}

The institutional denial of victimhood to Black transgender individuals communicates a societal judgment that people who behave in gender nonconforming or gender nonbinary ways are less deserving of protection from violence-especially sexual violence-because they engage in behavior of which we disapprove. Sexual assault advocates are familiar with these gender normative judgments, wherein burdens are placed on the (female) victim to prevent being raped by the (male) perpetrator. Women ought to take simple safety precautions (that men do not have to take), make smarter decisions (expending mental energy not required of men), or not put themselves "in the wrong place

\footnotetext{
${ }^{120}$ Rolnick, supra note 23, at 1654.

${ }^{121} I d$. at 1654-55.

122 See supra notes 11-14 and accompanying text.

123 See Lee, supra note 48, at 1411 ("The trans panic defense is not a traditional criminal law defense. ... Rather, trans panic is a defense strategy associated with the provocation or heat of passion defense. A murder defendant ... will claim that the discovery that the victim was a transgender female ... provoked him into a heat of passion, causing him to lose his selfcontrol."); id. at 1428 n.108 (summarizing successful gay and trans panic defenses).
} 
at the wrong time" (places and times that are not off limits to men). In short, women ought to work diligently not to get raped. ${ }^{124}$

This type of victim-blaming mentality derives from the myth of the "perfect victim," 125 the pure, virginal, modest, White woman who did nothing to provoke or invite her attack, and who is thus morally blameless. ${ }^{126}$ Despite the \#MeToo Movement's attempts to direct attention to the nuances of sexual assault, and particularly the nuances of victim responses in vulnerable, coercive settings, society still identifies "the image of the "victim' ... [as] a blameless, pure stereotype, with whom all can identify." 127 A "victim" is "an elderly person robbed of her life savings, an 'innocent bystander' injured or killed during a holdup, or a brutally ravaged rape victim. 'Victims' are not prostitutes beaten senseless ... drug addicts mugged and robbed ... or misdemeanants raped by cellmates." 128

These gender normative, sexist, racist moral purity tests simply leave no room for a Black transgender victim of (sexual) violence. They institutionalize and reinforce that an already marginalized population is simply less deserving of society's protection because of its perceived moral inferiority. Indeed, the "perfect victim" fallacy to which Black transgender victims are subjected represents a core dehumanization beyond the behavior-based shaming of most rape

${ }^{124}$ See, e.g., Charlotte Hilton Andersen, How to Teach Girls How Not to Get Raped, GrEAT FITNESS EXPERIMENT (Jan. 10, 2013, 10:15 AM), http://www.thegreatfitnessexperiment.com/ 2013/01/how-to-teach-girls-how-not-to-get-raped.html [https://web.archive.org/web/201301 16230352/http://www.thegreatfitnessexperiment.com/2013/01/how-to-teach-girls-how-notto-get-raped.html] (describing a self-defense class in which the teacher told young girls to report any attempted assault or rape "[b]ecause if you don't report it - what if your best friend comes walking along that same path [two] weeks later and gets raped? If you don't report it then it's your fault if other girls get hurt," and offering suggestions for teaching prevention of sexual assault in ways that would not shift responsibility to victims); KATIE Roiphe, The Morning After: Sex, Fear, And Feminism on Campus 9 (1993) (describing the first week of college for a female student, where "there are fliers and counselors and videotapes telling us how not to get AIDS and how not to get raped, where not to wander and what signals not to send").

125 This use of the phrase "perfect victim" does not refer to the mythical "perfect rape victim," who responds to unwanted sexual advances in the manner preferred by judges and juries-by screaming, offering forcible physical and verbal resistance, and by immediately calling the police and submitting to a medical examination. See Kelly Alison Behre, Ensuring Choice and Voice for Campus Sexual Assault Victims: A Call for Victims' Attorneys, 65 DRAKE L. REV. 293, 352 (2017) (“[There is a] harmful rape myth . . . of the 'perfect victim,' promoting the idea that real victims of sexual assault respond to trauma in one uniform manner.").

126 See Martha Chamallas, Lucky: The Sequel, 80 InD. L.J. 441, 442 (2005) (describing the mythical " 'perfect' [rape] victim, who is young, white, and a virgin"); see also Hannah Brenner et al., Bars To Justice: The Impact of Rape Myths on Women in Prison, 17 GEO. J. GENDER \& L. 521, 540 (2016) ("Rape myths inform the 'ideal victimhood' requirement that a victim be 'carrying out a respectable project' and is 'not to be blamed." ").

127 Lynne N. Henderson, The Wrongs of Victim's Rights, 37 STAN. L. REv.937, 951 (1985).

${ }^{128} I d$. 
victims. Rather than critiquing the actions of this community as risky and blameworthy, this trope attacks the very personhood of the victim, critiquing the racial and gender identity central to their existence.

\section{CONCLUSION}

The experience of Black transgender people in the criminal legal system reflects a "legac[y] of an exclusionary politics of protection," wherein they are not entitled to the law's protection when they need it most but instead unjustly face its punishment by virtue of their existence. ${ }^{129}$ This vulnerable intersectional community experiences criminal violence at rates far in excess of the national average, yet their attempts to seek state protection result in a dangerous mixture of ambivalence, discrimination, and state-sanctioned violence.

Faced with this reality, the Black transgender community desperately needs access to the law's recognition of protective self-defense. Legislative expansions of core self-defense doctrine, problematic as they are for many marginalized communities, should represent an opportunity for this community to exercise lawful self-help measures as a last (and often only) resort. Unfortunately, this exclusionary politics of protection not only excludes Black transgender violence victims from police protection but from legal self-protection when they stand their ground and fight back against their assailants. This Essay highlights the dual problems of under-protection and over-punishment. The solutions - more equitable, just, and compassionate treatment of Black transgender victims of crime-seem obvious. While this Essay does not attempt to sketch out an infrastructure for reform, hopefully shining a light on the problem can inform the urgent conversations to come.

129 See Kali Nicole Gross, African American Women, Mass Incarceration, and the Politics of Protection, 102 J. AM. Hist. 25, 25 (2015). 
[Vol. 21:3

[THIS PAGE INTENTIONALLY LEFT BLANK] 